\title{
The Usage of Gender-neutral Friendly Addresses in the Russian Language on the Example of the Address CHuvak 'Dude'
}

\author{
Ekaterina Sobko \\ High School of Economics \\ 20 Myasnitskaya str., \\ Moscow 101000 \\ Russia \\ sobkatya@gmail.com
}

\author{
Irina Fufaeva \\ Russian State University \\ for the Humanities \\ 6 Miusskaya sq., Moscow 125993 \\ Russia \\ irieleinbox.ru
}

\begin{abstract}
In this research friendly informal address chuvak is viewed as potentially gender-neutral: the one that can be used towards a person regardless of his or her gender. The phenomenon was identified and described by analyzing two datasets: mass polling results and a collection of Twitter posts. According to the mass poll, chuvak is perceived as gender-neutral address by a third of the female respondents (mostly by women under 20). To get the other dataset, we used the MAXQDA application. As a result of this study, 47 of 100 posts used chuvak to address a woman. These results may reflect natural processes in the modern Russian language associated with changes in the gender sphere.

Keywords: Russian language; address; jargon; gender semantics; corpus linguistics
\end{abstract}

DOI: $10.28995 / 2075-7182-2021-20-1206-1213$

\section{Использование гендерно-нейтральных дружеских обращений в русском языке на примере обращения чувак}

\author{
Ekaterina Sobko \\ Высшая школа экономики \\ 101000, Россия, Москва, \\ ул. Мясницкая, 20 \\ sobkatya@gmail.com
}

\author{
Irina Fufaeva \\ Российский государственный \\ гуманитарный университет \\ 125993, Россия, Москва, \\ пл. Миусская, 6 \\ irieleinbox.ru
}

\begin{abstract}
Аннотация
В этом исследовании дружеское неформальное обращение чувак рассматривается как потенциально гендерно-нейтральное: такое, которое можно использовать по отношению к человеку независимо от его пола. Явление было выявлено и описано путем анализа двух баз данных: результатов массового опроса и коллекции сообщений в Twitter. Согласно массовому опросу, чувак воспринимается как гендерно-нейтральное обращение третью респонденток (в основном, женщинами до 20 лет). Чтобы получить другой набор данных, мы использовали приложение MAXQDA. В результате этого исследования 47 из 100 сообщений использовали чувак для обращения к женщине. Эти результаты могут отражать естественные процессы в современном русском языке, связанные с изменениями в гендерной сфере.
\end{abstract}

Ключевые слова: русский язык; адрес; жаргон; гендерная семантика; корпусная лингвистика

\section{Introduction}

Currently, Russian language is undergoing certain changes that reflect the switch of gender semantics and are connected to a respective switch of gender discourse. Particularly, new gender-specific job titles 
were introduced by activists. However, it is crucial as well to study other linguistic phenomena that also reflect such sociocultural changes. For instance, such can be found in friendly addresses, which is the theme of this article.

The usage of terms of address of feminine or masculine gender towards the people of "the opposite" gender is noted throughout different periods of the modern Russian language.

For example, at the end of the 19th century, as evidenced from fiction prose, the addresses mamochka ('mommy') and golubushka (female diminutive of "pigeon", used as "dear"), when friendly, could be used in a variety of contexts, including communication between men. Maxim Kronhaus notes: "The address mamochka eliminates the distance between the interlocutors, as if they were relatives. In addition, in a conversation between two adults, the speaker takes a patronizing position over the addressee" [3]. For instance, in the comic play "The Proposal" by A.P. Chekhov (1888):

(1) Chubukov (approaching him): Golubushka, who do I see! Ivan Vasilyevich! Very glad! (shakes hands.) What a surprise it is, mamochka... How are you?"

Lomov: Thank you. And how are you doing?"

From 18th century to the beginning of 20th, the word brat 'brother' in combination with female names is sometimes used as a friendly or familiar address to a woman:

(2) Well, brother, Dasha, You can even plant a garden in the pie. [I. A. Krylov. Pie (1799-1801)];

(3) No, brother Aniutka, it seems you are no good, as I'm looking at you!... V. V. Krestovsky. Panurge's herd (Part 3-4) (1869)];

(4) Brother Mariia, I, have drunk from grief a little. [D. N. Mamin-Sibiryak] Gold (1892)];

(5) Yeah, brother Katiusha, - here you have to forget about oysters... [Valentin Kuritsyn. Tomsk slums (1906)];

(6) You see, she wants to blame it on me. No, brother Natalia, you can't trick me like that. You've taken the wrong sow by the ear. I see everything.[A. M. Kollontay. Big Love (1927)];

(7) Don't let it get you down, brother Nastukha, the wind is blowing hard from the sea [N. P. Kolpakova. Tersky Coast (1936)] (all examples taken from the Russian National Corpus).

There is evidence that during the 1960s, friendly addresses starik 'old man' and muzhik 'man's man' could be used as gender-neutral inside a certain, clearly defined group of young intellectuals. For example, the chapter "Muzhiki" - Khrushchev Thaw's last breath, the "Sixties on the faculty of physics of Leningrad State University" book is started by K.E. Voevodsky with two of such examples. First, the author quotes a satirical instruction "How to Write About Physicists":

(8) "Starik, have you already breastfed Alyoshka?"

Later he states that in the mid-60s there was a group of Komsomol activists, inside of which the address muzhik was used, disregarding the gender of the addressee ${ }^{1}$. All in all, such usage is a rare phenomenon.

Out of friendly contexts, the address tovarisch 'comrade' is another notable example of gender neutral address. This is a standard soviet way to address a person, who is, in most cases, a stranger to the speaker. However, this word could designate a woman even before the times of the Soviet Union. Here is an

\footnotetext{
${ }^{1}$ http://libed.ru/knigi-nauka/626998-21-udk-82-94-bbk-9ya94-sh51-proekt-organizaciya-lavrov-fedorov-sostaviteli-butorinadrukarev-lavrov-pogodin-fe.php
} 
example of such usage from the beginning of the 18th century: V.N. Tatischev in "Testament to My Son" (1734) wrote:

\section{(9)"... a wife is not a slave to you, but a tovarishch"}

As seen in the examples, using addresses that contradict gender semantics could add to expressiveness, intimacy or de-emphasise the importance of gender in the communication of a certain community. One current trend of gender neutralization is the use of the male-gendered word chuvak 'dude' by women and in reference to women. This article reports the findings of such usage. Our research methods were: corpus analysis; questioning; Twitter analysis with MAXQDA application ${ }^{2}$.

\section{The History of the word CHuvak, According to the Russian National Corpus, Google Trends and Corpus of Diaries "Prozhito"3}

Chuvak is not specified as an address. In the Russian National Corpus the word is more frequent as a common noun, than as an address. The quantity of addresses is only $28 \%$ out of all the entries.

The word remains common and even "fashionable" in modern youth slang ([1], [7]), while it has a rather impressive age for a slang unit. As it is showed in the article [8], the word chuvak, both as an address and as a nomination, was transferred from the slang of restaurant musicians - "labukhs" - to the slang of youth music bands that were oriented towards Western culture, mainly Western music, during the 1950s. Later, especially after the publication of Vasiliy Aksenov's novel "Star Ticket" in the "Yunost" magazine, it has become widely used among a broader young audience. This follows from the analysis of Russian National Corpus, Google Trends collection and "Prozhito", which is a corpus of digitized diaries. Despite the word's wider spreading, its initial connotations, connected to the western culture (music) remained. The word, thus, was typical for the speech of the youth, whose beliefs were different from the mainstream soviet ideology. This was also expressed through their style of communication.

The word continued to exist and is still used nowadays. The analysis of the more than 60 year history of the word's function in the language has shown that the word was exclusively men's during a considerable period of time. This means, it was only used by men to address men.

The most important sources here are documentary texts, memoirs, or fiction with at least some autobiographical features.

The emergence, together with the increasing frequency of usage of the word in the 1950-1960s is shown, firstly, in the sources of that time, beginning with the novel "Young Men" (1958) ${ }^{4}$ of Aron Erlih and in the school diary of Lydia Barlas (later, linguist L.V. Knorina), included in the "Prozhito" corpus (1958). Secondly, it is shown in the texts that were written decades after that time: in Vasiliy Aksenov's autobiographical novels "In Search of Sad Baby" (1987), in Eduard Limonov's "Savenko, the Teenager" (1982), in memoirs of the saxophonist Alexey Kozlov "Goat on Sax" (1998), where there is a mention of the address chuvak used during the years 1950-1951, etc. In all the texts that are set in that period of time, it is a term of address used by and referring to exclusively men. The only exception is found in "Rachel" (2003), the novel by Andrey Gelasimov, where the main character is referred to as chuvak by his girlfriend in his memories of the 1960s. However, this source cannot be considered documentary, since the author was born in 1966.

In the sources that include later usage, the address remains exclusively men's in the described way. This situation began to change in 2005, when the spoken Russian National Corpus started to include contexts (recordings of students' speech). There, the word is first seen as used by women. As a result, in 11 out of 38 contexts (29\%) of the spoken Russian National Corpus, the addressers of the word are women.

(8) [Alina, f., 21, 1984, student] I'm saying to him/"Chuvak/ this is not a taxi/ this is an apartment/ we're already sleeping here". [A conversation between three women (2005)// from the collection of Russian National Corpus].

\footnotetext{
${ }^{2}$ https://www.maxqda.com/

${ }^{3} \mathrm{https} / / /$ prozhito.org/

${ }^{4}$ https://libcat.ru/knigi/proza/sovetskaya-klassicheskaya-proza/28960-3-aron-erlih-molodye-lyudi.html\#text
} 
Regarding the current state of the Russian language, N.A. Osmak believes that "it is impossible to speak about the unambiguous specificity of the anthropolexeme chuvak for male or female speech" (based on a survey of 100 respondents - 50 men and 50 women) [6].

In General Internet-Corpus of Russian (GICR), "VKontakte - Cassandra" subcorpus (based on VKontakte social network), where there is data about the gender of the addresser, 97 results published between the years 2014 and 2015 were retrieved via the request "show 100 results" (the messages contained the word chuvak and had the gender of the author specified). Out of 97 entries, 38 were addresses. Unfortunately, not all of them were valid: 13 of them were copypasta. Out of the remaining 25 entries, 19 (about three fourths) were written by women. Though it was mainly impossible to figure out the gender of the addressees, out of 9 cases where a name or a link to page were specified, 5 referred to men (by 4 women and $1 \mathrm{man}$ ) and 4 referred to women (all of them by other women). Additionally, about one third of women authors had a "year of birth" feature specified in the dataset, and in all cases it was between 1997 and 2000. Taking into consideration the year of publication of the messages (2014), we may say that at least some of the female authors were between 14 and 17 years old. Out of 6 entries where the authors were men, the year of birth was specified for 4 of them: in 2014 they were 26, 25 and 18 years old.

The phenomenon of using chuvak to address a teenage girl was earlier mentioned by the linguist Irina Levontina in her book "What is it all about" (p.278): "Many sensitive parents, myself included, have noticed that children are now using the word chuvak referencing a girl as well: Chuvak, was it you who called me?, Call that chuvak (about a female classmate)" [4].

During the study of friendly addresses in 2019, the question of addresse's gender was included into the mass poll. Olga Leschenko, a student of HSE, took part in conducting the poll.

\section{The Analysis of the Questionnaire Regarding the Use of the Address CHuvak as Gender-neutral}

The questionnaire was filled out by 139 people. After the process of reviewing, 135 valid responses remained. The questionnaire was created using Google Forms and distributed via social networks.

The age of respondents is the following: under 20 years $=44 \%$ (59 people); $20-29$ years $=15 \%$ (20 people); $30-39$ years $=16 \%$ ( 21 person); $40-49=19 \%$ (26 people); $50-59=4 \%(5$ people $) ; 60-66=$ $3 \%$ (4 people). In total, the quantity of respondents of student age (17-22 years) was $51 \%$ (69 people).

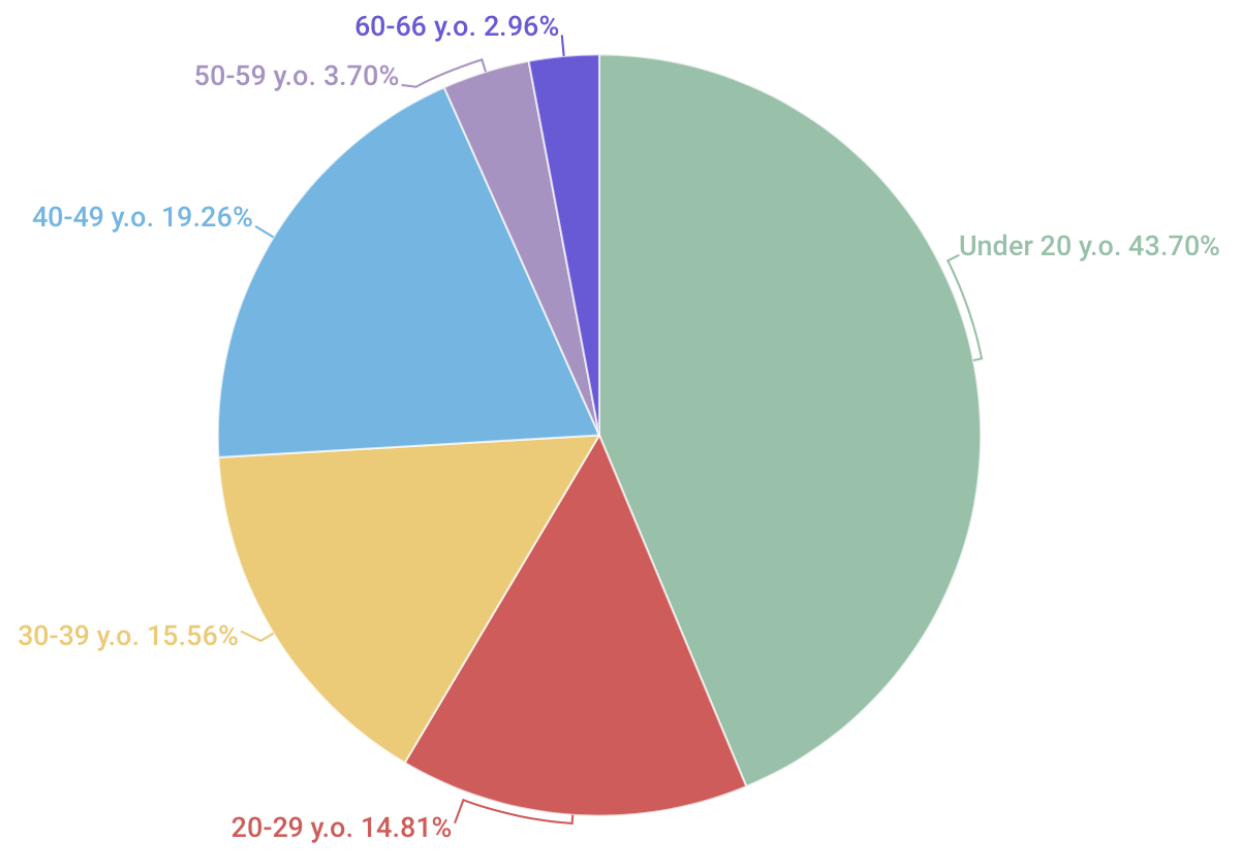

Figure 1: age of respondents 
Gender: $69 \%$ female (93 people), 31\% male (42 people). Education: from incomplete higher education to the degree of Candidate of Sciences. Places of residence are Moscow, the Moscow region; regional centers (Kazan, etc.); industrial cities (Salavat, etc.). The respondents' places of birth, in addition to Moscow and Moscow Region, are different regions of Russia, and, in one case, Georgia. The majority of respondents under 23 study at RSUH, HSE, MSU, MSEI, Plekhanov REU; older respondents work in the field of psychology, management, marketing, it, science and education. 57,4\% of respondents have described their sociability level as high (4 and 5 out of 5).

$41 \%$ of respondents have reported that they use chuvak in their speech. Among men, $48 \%$ use chuvak regularly as an address. $55 \%$ of the men surveyed ( 23 people) have reported that they are sometimes referred to as chuvak. $65 \%$ of the respondents of all genders have reported that they have heard somebody referring as chuvak to somebody they know.

The main difference between the results of the questionnaire and the analysis of Russian National Corpus is that women have reported to use the address chuvak only 1.3 times less often than men do.

Women who use this address are on average younger than men. Among the men that have reported using the term of address chuvak, $75 \%$ are under 30 years old, their average age is 25 . Among the women who reported using the address chuvak, $82 \%$ are under 30, their average age is 21 .

According to the questionnaire, women can also be the addressees of the word. It appears that whether the term of address is perceived as gender-neutral depends on the gender and age of the respondent. This was reported mainly by 31 young women ( 24 of them are under 25 years old, their medium age equals 23 , but the mode value is 18 ; this is one third of the people surveyed in total) and by 8 men aged between 18 and 25 .

However, fewer female respondents reported that they are actually called chuvak: only $10 \%$ of the total people surveyed ( 9 people, 8 of whom are aged between 17 and 21).

The fact that women consider any gender of the addressee of the word chuvak acceptable may be explained by the existence of all-women friend companies/couples, mainly of younger age, where women address each other this way.

Speaking of perceiving the term of address chuvak (among the women who have not chosen "I am not addressed like this"), the most common answer is "normal" (one third), followed by "positive" (one fifth), "strange" (just below one fifth), "repulsive" (11\%).

It is interesting that chuvikha (feminitive of the word chuvak), as shown by the questionnaire results, is considered not used, rude or disrespectful by the respondents. This shows little knowledge of this word, even if in the 1960s it had equally positive connotations, as the word chuvak had. One reason for present days students' wide usage of the term of address chuvak, that was popular among the generation of those who are now over 80 years old and was thereafter consider outdated, could be the fact that, since 1990s the word chuvak is used to translate the informal address dude (and sometimes slacker) in American movies, including its titles. This is a relatively new interpreting tradition: there are only 4 entries of the word chuvak (years 2004 and 2006) in the parallel English Language Corpus of Russian National Corpus.

Mosten oftenly respondents associate the word chuvak with the following movies:

- "The Big Lebowski" by the Coen brothers (1998), one of the characters of which was nicknamed Dude;

- a comedy movie "Dude, Where's my Car?" by Danny Leiner (2000);

- a parody thriller "Scary Movie" by Keenan Ivory Wayans (2000);

- a comedy "Dude" by Olivia Milch.

They also provide broader associations like "American movies about teenagers", "movies about criminals", "rap", "American movies in Russian voice acting", etc.

Since the questionnaire has shown that women use the address chuvak almost as frequently as men do and can also be referred to with this word, this phenomenon required additional research. 


\section{Study of the Use of the Address CHuvak in the Social Network "Twitter"}

In order to confirm the presence of tendency to gender-neutralize the address, to understand how explicit the tendency is and to identify possible characteristics of a person who can refer to women as chuvak, it was decided to analyse how the address is used in social networks.

To do this, we extracted data containing the word chuvak from the social network "Twitter". We decided to work with data from this social network, because it is relatively easy to get a dataset of recent tweets that would contain the word we are interested in. Moreover, Twitter is a social network in which user-generated content is mainly text messages: the two types of the content are "tweets" and "replies" (responses to tweets that form threads). Such a feature is also a benefit over VKontakte: it is easier to get cleaner data, since the replies contain copypasta less frequently than ordinary posts. The users of the social network are very diverse, and it is impossible to say if there is a prevailing opinion or political position among them. The algorithms of Twitter also play a rather weak role in content displaying. When a special lexical unit is searched, the algorithms do not interfere with it at all.

Thus, to get the dataset, we used the MAXQDA application, which is widely used in marketing research. The application allowed us to get a table in Excel format containing the last (as of July 9, 2020) thousand of tweets and replies published by the users that include the address "chuvak". To every tweet the following related information was attached:

1. Date and time of publication;

2. Hashtags;

3. Publication type (binary: tweet or reply);

4. Username (short name in latin characters, written with " @ " at the beginning) of the sender;

5. Sender's name (a longer name that can be written in characters of any alphabet);

6. Recipient's username (if it is a reply);

7. Geolocation of the author (specified optionally in the profile);

8. The time zone of the author, the author's link (specified in the profile, in most cases leads outside of Twitter);

9. Description of the author's profile (written by the author himself; cannot contain more than 140 characters);

10. The number of followers of the author;

11. The number of users the author follows;

12. Number of tweets in the author's profile;

13. Profile verification (binary: true or false. Verified accounts are usually owned by celebrities or corporations);

14. Date of author's profile creation;

15. The number of retweets (reposts) of a tweet or a reply;

16. Number of likes on a tweet or reply;

17. Language of the tweet or reply;

18. The source of the message (information about the device from which the tweet was sent, for example, "Twitter for Android");

19. The coordinates of the tweet.

To form the dataset for further analysis, tweets and posts on languages other than Russian were removed from the initial document. After that, the document consisted only of replies in Russian. Features $7,8,13-16,18,19$ were not directly related to the study, so this data was removed as well. Characteristics $10-12$ were used after the data labeling as additional information about the users.

Then the collected data was manually labeled and analyzed. The purpose of the analysis was to find out the gender identity of the recipient of the reply. Some usernames or recipients' names contained proper names that could be identified as male or female or the gender identity as a man or a woman was marked in the username in some other way (for example, "@MaryCastleberr9" or "@zabuivchivaya" the last one literally translates as "forgetful" and has a female adjective ending). Such cases left no doubts about the user's gender identity. Other users' pages had to be inspected manually in search for the presence of gender markers on them. The following was considered such markers: 
A. Specifying gender pronouns on the page;

B. Usernames that contain a reference to a female or male name;

C. The feminine or masculine endings of past-tense verbs or adjectives related to the user's description or his or her actions.

Replies through which gender identity of the addressee could not be identified in any of the described ways, or the user identified as non-binary were excluded from the dataset. Replies addressed to women were marked in green, while those addressed to men were marked in red. As a result, 100 tweets remained in the dataset. In these, the word chuvak was addressed to a specific user who identifies himself or herself using one of the genders: female or male.

Finally, it turned out that the number of the times somebody was addressed chuvak was nearly equal for men and women: out of 100 replies 47 (or 47\%) were addressed to users that identify as women, while 53 (or 53\%) were addressed to those who identify as men. Out of 47 replies addressed to women 22 (or 47\%) were written by other women. One third of these women ( 7 authors or $15 \%$ ) indicate their gender pronouns in their profile in Russian or in English languages, which shows their awareness of the gender activism agenda. 15 users (or $32 \%$, which is one third) have put their real names somewhere in the profile, 12 users (or $25 \%$, which is a quarter) have additionally expressed their interest in a fandom (a community of fans that share a common interest, usually in the field of culture).

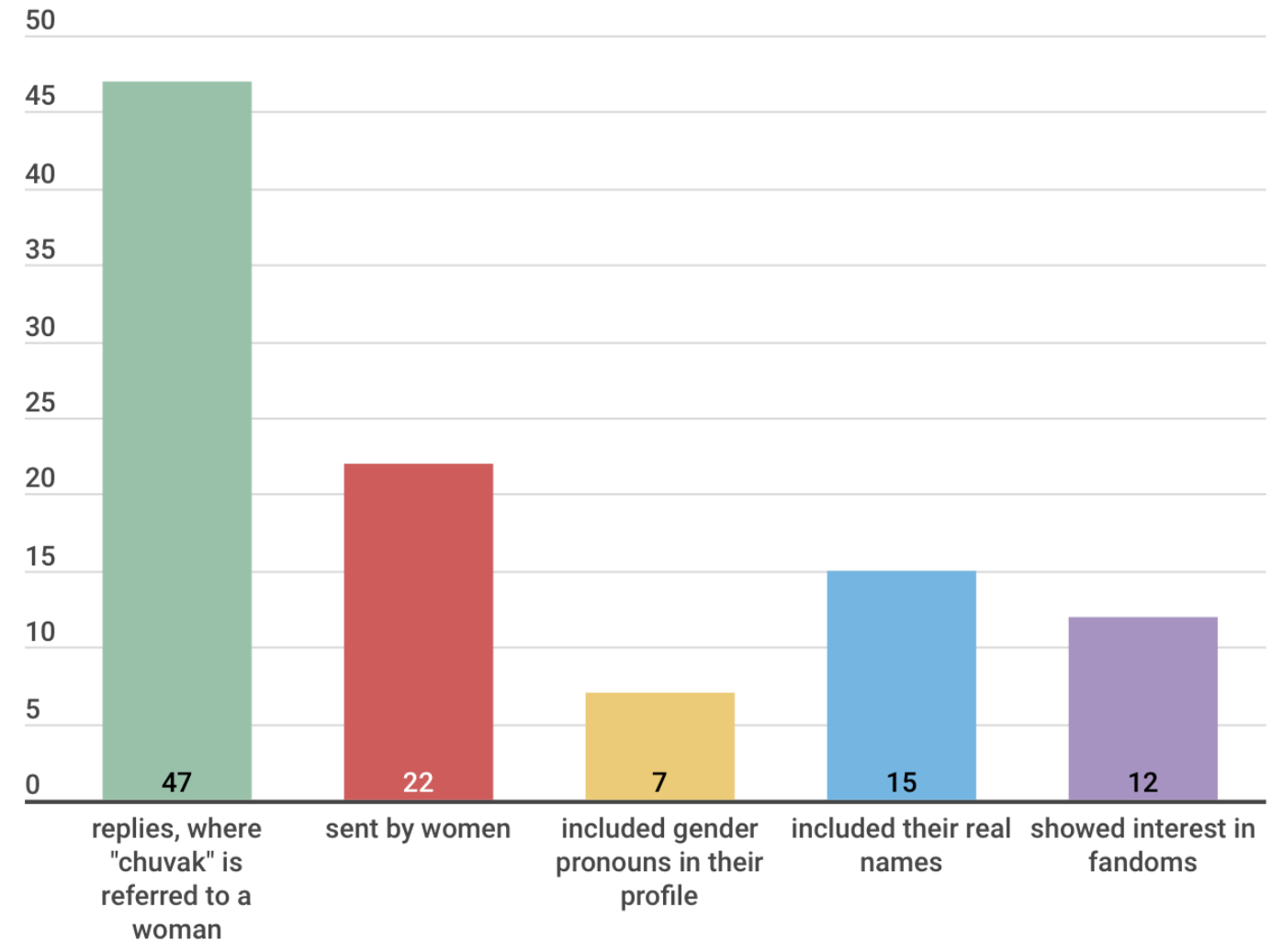

Figure 2: statistics of replies, where chuvak is referred to a woman

Analyzing the characteristics 10-12 of the dataset, it has turned out that the median number of posts of the users that address women as chuvak equals 3022, which shows that the pages are mostly personal (and not of celebrities or corporations). The average number of subscriptions and subscribers is 584 and 784 , respectively, which is usually true for accounts containing fandom or artistic content. This and the previous facts about the fairly frequent mention of fandoms in the description of the user account $(25 \%$, which is a quarter of all those who address women using the friendly address chuvak), make us assume that the gender neutralization of the address chuvak is especially common in the subcultural environment of books, movie, music and computer games lovers. Nevertheless, the data shows that this happens quite often among other users, including users with real names. 


\section{Conclusion}

Nowadays, the address chuvak is widely used as gender-neutral. This tendency is initially or largely subcultural in origin, which is generally typical of the informal components of the Russian language.

While studying the history of gender neutralization of the friendly address chuvak, it turned out that the practice of the word's usage by women to reference women, while not being well-documented, is now widely spreading. Moreover, the word in the masculine gender is generally better perceived by women than the feminine chuvikha. The study of data from the social network Twitter proves that at the moment, Internet users address women as chuvak almost as often as they call men chuvak, while not using it as a figure of speech, unlike in earlier attempts of gender-neutralisation.

Modern informational field is overwhelmed by the calls from opinion leaders to reform the use of certain words in the Russian language for the purposes of political correctness or inclusiveness. There are constant discussions about the use of new feminitives in the Russian language, the gender-specific occupation names (borrowed from other Slavic languages or artificially constructed). Words like avtorka (female author) and redaktorka (female editor) have provoked a lot of controversy and raised the question of how to speak about women in an inclusive way. The society is actively involved in the formation of new ideologically correct variants of words and their usage and voluntarily judges those who speak "in a wrong way". At the same time, natural language processes are not being noticed by the activists, even if such can reflect a similar or at least related ideological purpose.

Therefore, further research in the field may include the identification of other words that are undergoing the process of gender-neutralization.

\section{Литература}

[1] Беликов В.И. Чуваки унывают, или реальный способ конкретно отслеживать динамику узуса // Мода в языке и коммуникации. Сборник статей. Российский государственный гуманитарный университет, Институт лингвистики. - Москва, 2014. С. 56-82.

[2] Генеральный интернет-корпус русского языка (ГИКРЯ). Access mode: http://www.webcorpora.ru.

[3] Кронгауз М.А. Мамочка. Access mode: https://arzamas.academy/micro/etiket/17.

[4] Левонтина И.Б. О чем речь. - M: Corpus, 2015.

[5] Национальный корпус русского языка. Access mode: https://ruscorpora.ru/new/index.html.

[6] Осьмак Н.А. Чувак и чувиха в современной повседневной речи // Коммуникативные исследования. 2018. - №. 15 , c.45-48.

[7] Суркова В.А., Платонова Е.В. Молодежный сленг // Lingva academica: актуальные проблемы лингвистики и лингводидактики, материалы Всероссийской научно-практической конференции. - Ульяновский государственный университет, 2016.- с.190-195.

[8] Фуфаева И.В. Чувак и чувиха: исходная жаргонная принадлежность (в печати).

\section{References}

[1] Belikov V.I. CHuvaks disappear, or a real way to specifically track the dynamics of uzus [CHuvaki unyvayut, ili real'nyj sposob konkretno jnslezhivat' dinamiku uzusa] // Fashion in language and communication. Digest of articles [Moda v yazyke i kommunikacii. Sbornik statej]. — Moscow: Russian State University for the Humanities, 2014. - P.56-82.

[2] General Internet-Corpus of Russian (GICR). Access mode:http://www.webcorpora.ru.

[3] Krongauz M.A. (2018), Mommy [Mamochka]. Access mode: https://arzamas.academy/micro/etiket/17.

[4] Levontina I.B. What is it about [O chem rech']. - Moscow: Corpus, 2015.

[5] Russian National Corpus. Access mode: https://ruscorpora.ru/new/index.html.

[6] Osmak N.A. CHuvak and chuvikha in modern everyday speech [CHuvak i chuvikha v sovremennoj povsednevnoj rechi], Communication research [Kommunikativnye issledovaniya]. — 2018. — Vol. 15. P. $45-48$.

[7] Surkova V.A., Platonova E.V. (2016), Youth slang [Molodezhnyj sleng], Lingva academica: current problems of linguistics and linguodidactics, materials of the All-Russian scientific and practical conferences [Lingva academica: aktual'nye problemy lingvistiki i lingvodidaktiki, materialy Vserossijskoj nauchno-prakticheskoj konferencij]. Ulyanovsk State University, pp.190-195.

[8] Fufaeva I.V. (2021), CHuvak and chuvikha: original slang affiliation [CHuvak i chuviha: iskhodnaya zhargonnaya prinadlezhnost'] (in print) 